\title{
EFFECT OF SUPERVISION, MOTIVATION OF ACHIEVEMENT AND REWARD TO TEACHER PERFORMANCE WITH LEADERSHIP STYLE AS VARIABLES OF MODERATION
}

\author{
Muzakki Hidayat ${ }^{1}$ \\ Muhaimin Dimyati ${ }^{2}$ \\ Supardi ${ }^{3}$ \\ Higher Education of Economic Mandala \\ e-mail: muzakkihidayat4@gmail.com
}

\begin{abstract}
Supervision is one form of attention of the principal to the teacher in addition of giving rewards that can foster motivation of achievement that will give effect to the performance of teachers. If it supported by a leadership style, it will be able to improve teacher performance. This study aims to determine and analyze the influence of supervision, achievement motivation and reward on the performance of teachers and the influence of moderation leadership style on supervision, achievement motivation and reward on teacher performance. This research is a survey research conducted in $\mathrm{Al}$ Baitul Amien 02 Jember elementary school with sampling technique using total sampling technique, so that the sample obtained 40 respondents. Hypotheses were tested using multiple linear regression analysis and Moderated Regression Analysis (MRA). The results showed that supervision, achievement motivation and reward on teacher performance either simultaneously or partially. Leadership style has not been able to moderate the influence of supervision, achievement motivation and reward on teacher performance.
\end{abstract}

Keywords: Supervision, Achievement Motivation, Rewards, Performance, Leadership Style

\section{Introduction}

Education is the basic capital to create superior human resources. The main educational world is the school. School is one of alternative institution of education service. School as an institution certainly has a vision, mission, goals and functions. To carry out the mission, realizing the vision, achieving the goals and carrying out its functions the school requires professional staff, organizational work and sources that support both financial and non-financial.
Schools as a system have components that relate to each other and contribute to the achievement of goals. These components are students, curriculum, teaching materials, teachers, principals, other education personnel, environment, facilities, learning process and outcomes or outputs. All these components must evolve according to the demands of the times and environmental changes that occur around it. To develop, there must be a process of reform. This development should depart from the things that cause 
the organization can not function as well as expected (Gupta and Shingi, 2001).

Teacher performance in schools has an important role in achieving school goals. Optimal teacher performance is influenced by various factors, both internal and external. Meanwhile, teachers have the main task, namely: preparing the learning program, implementing the learning program, carry out the evaluation, carry out analysis of student learning outcomes, carry out improvements, remedial and enrichment (Aqib, 2010: 82).

\section{One form of principal attention given to school personnel is} supervision. Supervision is in the form of checks to ensure that what has been done is also intended to keep the leader alert to a potential problem before it becomes serious. Supervision is a basic process, similar to wherever it is and what is being watched. Effective leaders use supervision to share information, praise good practice and see those who need help and determine what types of help are needed (Purwanto, 2012:15).

Another factor that can improve teacher performance is work motivation. A teacher can work professionally if in itself there is high motivation. Highly motivated teachers will usually perform their duties energetically and energetically, as there are certain motives or goals that lie behind the action. The motive is the driving force that gives him power, so he wants and willingly works hard. This is evidenced based on the results of research by Mc Cleland (1961), Edward Murray (1957), Miller and Gordon W (1967) cited Mangkunegara (2005), concluded that there is a positive relationship between achievement motivation and achievement of performance / work performance. This means that leaders, managers and employees who have high achievement motivation will achieve high performance and vice versa those whose performance is low due to low work motivation.

According to Kurnianingsih and Indriantoro (2001: 22) the reward system is compensation to managers consisting of fixed payments and fixed payments plus variables whose amount is determined based on managerial performance. Mulyadi and Setyawan (2001: 227) define awards system is one of the important controlling tools used by companies to motivate personnel to achieve company goals (not individual goals) with behavior as expected by the company (not personally favored behavior).

The phenomenon that became the problem in SD Al Baitul Amien 02 Jember is not all teachers have the performance as expected, both from quality, quantity, efficiency of working time in realizing the vision and mission. Leadership factors affect the performance of this school. Lack of rewards for outstanding teachers, perform well and integrate a good work culture. And vice versa, less firmly of providing punishment for teachers who have poor performance and integration of work culture is not good. This can be seen when the supervision will be done, then the teacher will make the best possible device with a variety of good teaching methods in order to perform in the class much better than the condition of daily teaching and learning activities. The policies made by the leadership have considerable impact on teacher performance.

The purpose of this study is to know and analyze the influence of supervision, achievement motivation and reward simultaneously and partially to the performance and to know and 
analyze the influence of moderation leadership style to the relationship supervision, achievement motivation and reward with performance.

\section{Conceptual Framework}

The role of the principal as a supervisor is one of the factors affecting teacher performance. A principal must have leadership skills, so that he can do his role as principal effectively, showing good behavior and ability to lead a school organization. In his role as a school supervisor, the principal must be able to influence and direct all those involved in the educational process of teachers and work facilities in order to achieve the learning objectives as expected. In his leadership, the principal must be able to understand, address and correct existing deficiencies related to the learning activities undertaken in the school.

Supervision will be realized if a leader or principal gives instructions to his subordinates, conduct supervision and motivation so that it can lead to satisfaction for teachers so hopefully it can improve teacher performance itself.

Supervision conducted by the principal to the teachers is done regularly and scheduled with the hope that the teacher is able to improve the learning process undertaken. In the process, the principal monitors directly when the teacher is teaching. Teachers design learning activities in the form of lesson plans then the principal observes the learning process undertaken by the teacher.

Thus, when the style of leadership is applied properly and appropriately, it will give effect on employee performance through employee job satisfaction. Appropriate leadership is able to create a proper working environment and make employees feel comfortable in the work so that they feel happy and satisfied that will ultimately affect the performance of employees. The framework of thought in this study can be explained in the chart as follows:

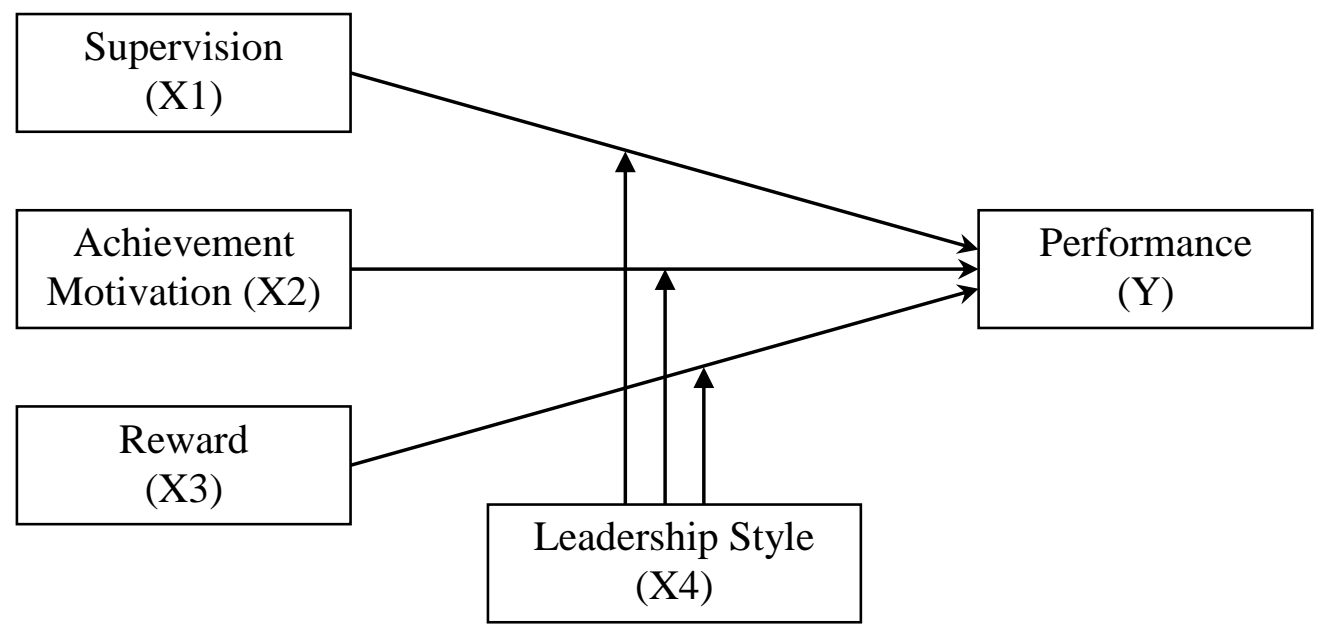

\section{RESEARCH METHODS}

This research was designed in the form of survey research. Survey research is a field study conducted on several samples from a particular population whose data collection is done by using a questionnaire (Zainal, 2007). The data used in this study is the primary data. The population in this research is the teacher at SD Baitul Amien 02 Jember within 40 teachers. The sampling technique used is total sampling, those are 40 respondents. 
Systematically path analysis follows the pattern of structural model, so that the first step to work on or application of this model of analysis, multiple linear regression equation and Moderated Regression Analysis (MRA) equation. The equation model used in this study can be explained by the following equation:

Multiple linear regression equation:

$\mathrm{Y}=\beta \mathrm{X}_{1}+\beta \mathrm{X}_{2}+\beta_{3} \mathrm{X}_{3}+\mathrm{e}_{1}$

Moderated Regression Analysis (MRA) equation:

$\mathrm{Y}=\beta \mathrm{X}_{1}+\beta \mathrm{X}_{2}+\beta_{3} \mathrm{X}_{3}+\beta_{4} \mathrm{X}_{1} \mathrm{Z}+\beta_{5} \mathrm{X}_{2} \mathrm{Z}$

$+\beta_{6} X_{3} Z+e_{2}$

Table 1, Characteristics of respondents

\begin{tabular}{|l|l|c|c|}
\hline \multirow{2}{*}{ Characteristics } & \multicolumn{2}{|c|}{ Description } & \multicolumn{2}{c|}{ Distribution } \\
\cline { 3 - 4 } & & Frequency & Percentage (\%) \\
\hline Gender & Male & 12 & 30,0 \\
& Female & 28 & 70,0 \\
\hline Age & 15-24 years old & 4 & 10,0 \\
& 25-34 years old & 29 & 72,5 \\
& 35-44 years old & 6 & 15,0 \\
Education & 45-54 years old & 1 & 2,5 \\
& Diploma & 1 & 2,5 \\
Years of service & Bachelor & 38 & 95,0 \\
& Master & 1 & 2,5 \\
& Less than 6 years & 29 & 72,5 \\
& 6-12 years & 9 & 22,5 \\
& 13-18 years & 2 & 5,0 \\
\hline \multicolumn{2}{|c|}{ Total } & 40 & 100 \\
\hline
\end{tabular}

The description of each characteristic is: mostly female $(70.0 \%)$, most respondents are aged in the range of 25-34 years $(72.5 \%)$, most respondents have recent education Bachelor (95\%), and most respondents have a working period of less than 6 years $(72.5 \%)$. Recapitulation of the results of multiple linear regression analysis is presented in Table 2 .
The test of hypothesis used is $\mathrm{F}$ test to test the influence of independent variable to dependent variable simultaneously, $\mathrm{t}$ test to test the influence of independent variable to partially dependent variable and $\mathrm{R}^{2}$ test to find out how much dependent variation caused by variation of independent variable (Supranto, 2000).

\section{RESULT ANALYSIS}

Characteristics of study respondents include age, sex, education level and years of service as presented in Table 1. 
Table 2, Results of Multiple Linear Regression Analysis

\begin{tabular}{|c|l|c|c|c|c|}
\hline \multirow{2}{*}{ Num. } & \multirow{2}{*}{ Independent Variables } & \multirow{2}{*}{$\begin{array}{l}\text { Regression } \\
\text { coefficient }\end{array}$} & \multicolumn{2}{|c|}{$\begin{array}{c}\text { Presentation of } \\
\text { hypotheses }\end{array}$} & \multirow{2}{*}{ Sign. } \\
\cline { 4 - 5 } & & & t-count & t-table & \\
\hline 1. & Supervision $\left(\mathrm{X}_{1}\right)$ & 0.164 & 2.092 & 2.030 & 0.044 \\
2. & Achievement Motivation $\left(\mathrm{X}_{2}\right)$ & 0.104 & 2.291 & & 0.028 \\
3. & Reward $\left(\mathrm{X}_{3}\right)$ & 0.147 & 2.036 & & 0.049 \\
$4 . \quad$ Leadership Style $(\mathrm{Z})$ & 0.544 & 4.161 & & 0.000 \\
\hline Constant & $=6.028$ & \\
$\mathrm{R}^{2}$ & $=0.978$ & \\
F-count & $=395.426$ & \\
F-table & & & \\
Significance & $=2.874$ & & \\
\hline
\end{tabular}

Based on the above results, it is known that the coefficient of determination $\left(\mathrm{R}^{2}\right)$ of 0.978 , which means that the independent variables (supervision, achievement motivation, reward and leadership style) affect the dependent variable (teacher performance) of $97.8 \%$, while the rest Of $2.2 \%$ is influenced by other factors outside the model. The F-count value of $395.426(\mathrm{p}=0.000)$ and the F-table value of 2.874 , means that the supervision variables, achievement motivation, reward and leadership style simultaneously have a significant influence on the dependent variable (teacher performance). The results of multiple linear regression analysis obtained regression equation as follows:

From the multiple linear regression equation above can be seen the influence of supervision variables, achievement motivation, reward and leadership style to the dependent variable (teacher performance), while the meaning of multiple linear regression equation above can be explained as follows:

1. The constant of regression equation $\left(b_{0}\right)$ is 6.028 , meaning that if there are no values on independent variable or independent variables equal to zero, it means the teacher's performance is positive.

2. The regression coefficient of supervision $\left(b_{1}\right)$ of 0.164 means that the improvement of teacher work supervision will be followed by the improvement of teacher performance with the assumption that other independent variables are constant. The t-value of the supervision variable is $2.092(\mathrm{p}=$ 0.044 ) and the t-table is 2.030. This indicates that partial supervision variable has significant effect on teacher performance.

3. The regression coefficient of achievement motivation $\left(b_{2}\right)$ of 0.104 means that the improvement of achievement motivation will be followed by the improvement of teacher performance with the assumption of other independent variables constant. The value of $t$ count of achievement motivation variable of $2.291 \quad(\mathrm{p}=0.028)$ showed that the variable achievement motivation partially significant effect on teacher performance.

4. The regression coefficient of reward $\left(b_{3}\right)$ of 0.147 means that the increase in reward will be followed by the 
improvement of teacher performance with the assumption of other independent variables constant. The value of t-count of reward variable is $2.036(\mathrm{p}=0.049)$ indicating that variable of reward partially have significant effect to teacher performance.

5. The regression coefficient of leadership style $\left(b_{4}\right)$ of 0.544 means that improvement of leadership style will be followed by improvement of teacher performance with assumption of other independent variables constant. The value of $t-$ count of leadership style variables of 4.161 ( $\mathrm{p}=0.000)$ indicates that leadership style variables partially significant effect on teacher performance.

The result of the influence of leadership style moderation toward the relationship between independent variables (supervision, achievement motivation and reward) with teacher performance is presented in Table 3.

Table 3, Result of Moderation Influence from Leadership Style to Relationship between Supervision, Achievement Motivation and Reward with Teacher Performance

\begin{tabular}{|c|c|c|c|c|c|}
\hline \multirow[t]{2}{*}{ Num. } & \multirow[t]{2}{*}{ Independent Variables } & \multirow{2}{*}{$\begin{array}{l}\text { Regression } \\
\text { coefficient }\end{array}$} & \multicolumn{2}{|c|}{$\begin{array}{c}\text { Presentation of } \\
\text { hypotheses }\end{array}$} & \multirow[t]{2}{*}{ Sign. } \\
\hline & & & $\mathrm{t}$-count & t-table & \\
\hline 1. & Supervision $\left(\mathrm{X}_{1}\right)$ & -0.682 & -0.812 & 2.037 & 0.423 \\
\hline 2. & Achievement Motivation $\left(\mathrm{X}_{2}\right)$ & 0.099 & 0.255 & & 0.800 \\
\hline 3. & Reward $\left(\mathrm{X}_{3}\right)$ & 0.744 & 0.690 & & 0.495 \\
\hline 4. & Leadership Style (Z) & 0.059 & 0.240 & & 0.812 \\
\hline 5. & Interaction of X1.Z & 0.012 & 1.040 & & 0.306 \\
\hline 6. & Interaction of X2.Z & 0.0002 & 0.033 & & 0.974 \\
\hline 7. & Interaction of X3.Z & -0.007 & -0.520 & & 0.607 \\
\hline \multicolumn{2}{|c|}{ Constant } & $=32.171$ & & & \\
\hline \multicolumn{2}{|l|}{$\mathrm{R}^{2}$} & $=0.984$ & & & \\
\hline \multicolumn{2}{|c|}{ F-count } & $=272.799$ & & & \\
\hline \multicolumn{2}{|c|}{ F-table $(5 \% ; 3 ; 32)$} & $=2.901$ & & & \\
\hline \multicolumn{2}{|c|}{ Significance } & $=0.000$ & & & \\
\hline
\end{tabular}

The influence of moderation of leadership style on the relationship between supervision, achievement motivation, and reward with teacher performance is described as follows:

a. The Influence of Moderation of Leadership Style on the Relationship between Supervision and Teacher Performance

Result of examination of influence of moderation of leadership style to supervision and teacher performance correlation, obtained $\mathrm{t}$ count value of supervision interaction and leadership style (X1.Z) equal to $1.040(\mathrm{p}=0.306)$ showing that leadership style variable not able to moderate significantly influence of supervision variable toward Performance of teachers.

b. The Moderation Influence of the Leadership Style on the Relationship between Achievement Motivation and Teacher Performance

Result of examination of influence of moderation of leadership style to the relation between achievement motivation and teacher performance, obtained t-count value of 
achievement motivation interaction and leadership style (X2.Z) equal to 0.033 $(\mathrm{p}=0.974)$ showing that leadership style variable not able to moderate significantly influence achievement motivation On teacher performance.

c. The Moderation Influence of the Leadership Style on the Relationship between Reward and Teacher Performance

Result of examination influence of moderation from leadership style to relation between reward and teacher performance, obtained t-count value of interaction between reward and leadership style (X3.Z) equal to -0.520 $(\mathrm{p}=0.607)$. This shows that the leadership style has not been able to moderate significantly the influence of reward on teacher performance.

\section{INTERPRETATION}

The principal is the most important person in a school, because he is the key for development and improvement of a school. Indicators of success school can be achieved if the school is functioning well, especially if student achievement can reach the maximum point. According to Carter in Sahertian (2000: 17), supervision is the efforts of school staff in leading teachers and other staff in improving teaching including stimulating, selecting teacher growth and development and revising educational goals, teaching materials, methods, and evaluation of teaching.

Achievement motivation is a motivator that originated in students to do learning activities to achieve a particular goal of achieving as high as possible. Teachers who have high achievement motivation will work harder when compared to teachers who are low motivated. Teachers with high achievement motivation tend to experience success in performing tasks assigned by the school. This is reinforced by Weiner (Wuryani, 1988: 161) that motivated teachers will continue to perform tasks longer than teachers who lack high-motivation to achieve, even after they have failed and linked their failures with no or less effort. Teachers who are motivated to achieve achievement wish to succeed and if they fail will try harder until they succeed.

Reward has an influence on the performance of teachers in completing tasks that are charged well and full of responsibility, so that ultimately can obtain maximum results. Each organization, especially schools can use various rewards to attract and retain teachers and motivate them to achieve personal goals and organizational goals. For example, by giving teachers in the form of wages, over duties, promotions, praise and recognition and helping to create a climate that produces jobs that have more challenges and satisfy. Instead, teachers will exchange them with time, ability, expertise, and effort to earn appropriate rewards. It is understandable that the main objectives of the reward system are: attracting qualified people to join the organization, keeping teachers coming to work, encouraging teachers to follow school rules and motivating teachers to achieve high levels of achievement. With a good reward, the teacher will be satisfied with the rewards obtained from the job. When the teacher is satisfied with what he has gained from school, then the teachers will exchange it with time, ability, expertise, and his efforts for the school then will work optimally so that the results of his work will be optimal in accordance with established performance standards.

Test results with Moderated Regression Analysis (MRA) showed 
that leadership style variables have not been able to moderate significantly influence the variables of supervision, achievement motivation and reward on teacher performance. Principal leadership style that is appropriate to the situation and conditions will be able to create a good working atmosphere in school, so it will give a positive influence on teacher performance level. If the applied style of leadership can precisely direct the purpose of the school with the aspects / objectives that individuals expect for their work, it is a highly possibility of creating a proper conditions or work environment for teachers, as well as the job satisfaction felt by the teacher. Teachers will feel comfortable in working without any pressure either from their colleagues or from the management on it. The style of leadership is one of the important factors that influence work behavior such as teacher satisfaction. The style of leadership directly influences performance through its careful workcreating and work environment, designation of responsibilities and good application of the rules. In other words, the better the applied leadership style, the better or higher performance of the teacher will be.

\section{CONCLUSIONS}

Supervision, achievement motivation, reward and leadership style simultaneously have a significant effect on teacher performance in Al Baitul Amien 02 Jember elementary school. Supervision, achievement motivation and reward partially have a significant effect on teacher performance in $\mathrm{Al}$ Baitul Amien 02 Jember elementary school. The leadership style has not been able to moderate the influence of supervision, achievement motivation and reward on teacher performance in
Al Baitul Amien 02 Jember elementary school.

To realize and improve teachers' performance, it requires a genuine effort both from the teacher itself and from the principal, for example improving the principal's role through supervision and leadership, improving teacher achievement motivation and rewarding the teacher. The role of the government is also indispensable in this regard to improve teacher performance.

\section{REFERENCES}

Dharma, A. 2003. Manajemen Prestasi Kerja, Jakarta: CV. Rajawali.

Kartono, K. 2008. Pemimpin dan Kepemimpinan. Jakarta: PT. Raja Grafindo Persada.

Mangkunegara, A.P. 2005. Evaluasi Kinerja SDM. Cetakan pertama. Jakarta: Refika Aditama.

Maryani, N. 2016. Pengaruh Supervisi Kepala Sekolah dan Kompetensi Profesional Guru terhadap Kinerja Guru di SMP Islam Kecamatan Ciawi Bogor. Tesis. Surakarta: Program Pascasarjana Program Studi Manajemen Pendidikan Islam Institut Agama Islam Negeri Surakarta.

McClelland, D. 1961. The Achieving Society. New Jersey: Van Nonstrand Company, Inc.

Mulyasa, E. 2007. Menjadi Guru Profesional. Bandung: PT Remaja Rosdakarya.

Purwanto, N. 2012. Administrasi \& Supervisi Pendidikan. Bandung: Remaja Rosdakarya.

Sahertian, P. 2000. Supervisi Pendidikan dalam Rangka Inservice Education. Jakarta: Rineka Cipta. 
Supranto, J. 2000. Statistik Teori dan Aplikasi. Bandung: PT. Gelora Aksara.

Wuryanto, A. 2005. Pengembangan Bahan Ajar. http://aguswuryanto.wordpress.c om/ 2010/09/02/pengembanganbahanajar/ diakses 12 Januari 2016. 